\title{
Menutup celah korupsi melalui kolaborasi antar aktor dalam pengawasan keuangan negara
}

\author{
Dian Iskandar \\ Universitas Diponegoro, Semarang
}

\begin{abstract}
INTISARI
Menekan angka korupsi dan mengungkap kasus korupsi agar menghindarkan negara dari kerugian menjadi tantangan tersendiri bagi para aktor pengawasan keuangan negara. Oleh sebab itu, tulisan ini bertujuan untuk mengelaborasi upaya yang dilakukan untuk mengawasi praktik penyimpangan keuangan negara yang dilakukan oleh aktor pengawasan keuangan negara. Metode pengumpulan data yang dilakukan melalui desk study. Beberapa upaya yang dilakukan dalam pengawasan keuangan negara itu diantaranya: Pertama berupa kolaborasi, komitmen, koordinasi dan sinergitas antara Inspektorat, BPKP, BPK dan lembaga legislatif, dengan menggunakan standar pemeriksaan dan sistem pengendalian internal. Kedua terkait dengan waktu pengawasan yang dilakukan feedforward, concurrent, dan feedback control. Ketiga yaitu sifat pengawasan baik represif maupun preventif akan mampu menutup celah yang biasanya dimainkan dalam penyalahgunaan keuangan negara.
\end{abstract}

\section{KATA KUNCI}

Aktor Pengawasan; Keuangan Negara; Pengawasan Keuangan Negara

\section{Pendahuluan}

$\mathrm{P}$ engelolaan keuangan negara menjadi isu yang tidak akan ada habisnya untuk dibahas, mulai dari perencanaan, pelaksanaan, penatausahaan sampai pada pelaporan dan pertanggungjawaban, hal ini dikarena keuangan negara menjadi fundamental financial support bagi pemerintah dalam menyelenggarakan pemerintahan, penyediaan dan pendistribusian pelayanan dan barang publik dan untuk kepentingan kesentosaan rakyat. Office holder, para pemegang kekuasaan dan wewenang menjadi penanggungjawab atas pengelolaan keuangan negara tersebut. Namun tidak sedikit diantara mereka merogoh celah-celah untuk bisa menikmati uang negara untuk kepentingan personal dan memperuntukannya bukan yang semestinya. Menjadi

\section{Korespodensi:}

Sekolah Vokasi, Prodi Keuangan Publik, Universitas Diponegoro, Jl. Prof. Soedarto, Tembalang, Kota Semarang, Jawa Tengah 50139.

Email: dianiskandar@live.undip.ac.id 
Dian Iskandar $\mid$ Menutup celah korupsi melalui kolaborasi antar aktor dalam pengawasan...

tidak mengherankan pada tahun 2018 bahkan tahun-tahun sebelumnya banyak para pemegang kekuasan, dan pemilik kewenangan, mulai dari aparatur sipil negara, kepala daerah sampai wakil rakyat yang terhormat melakukan kejahatan kerah putih yang mengakibatkan kerugian negara atas tindakan korup yang dilakukan (Tempo.co, 2018). ${ }^{1}$

Berdasarkan trend penindakan kasus korupsi semester 1 tahun 2018 yang diliris oleh Indonesia Corruption Watch menemukan 139 kasus dengan 351 orang tersangka yang mengakibatkan kerugian negara sebanyak 1,09 triliun rupiah dan nilai suap sebanyak 42,1 miliar rupiah (Alamsyah, Abid, \& Sunaryanto, 2018). Ditahun yang sama, Komisi Pemberantas Korupsi (KPK) melakukan setidaknya 30 Operasi Tangkap Tangan (BBC Indonesia, 2019). Tujuannya tidak lain yaitu untuk menciptakan good and clean governance. Menjadikan negara yang besar ini bersih dari korupsi, kolusi dan nepotisme merupakan tantangan yang harus ditaklukan oleh pemerintah.

Melalui Komisi Pemberantas Korupsi yang dibentuk secara khusus untuk membasmi tindak pidana korupsi, dan lembaga penegak hokum lainnya. Berbagai upaya terus dilaksanakan terlihat dari naik sebanyak 7 peringkat dari tahun sebelumnya. Hasil Indeks Presepsi Korupsi yang diliris oleh Transparency International terbaru menunjukan bahwa Indonesia pada 2018 menepati peringkat 89 dari 180 negara dengan score 38 dari 100 (Transparency International, 2018). Kondisi ini menujukkan upaya serius dan agresif pemerintah untuk menciptakan good and clean governance yang selama ini didambakan serta memberikan kesejahteraan bagi rakyatnya.

Selain itu terdapat lembaga yang bebas dan mandiri yang dibentuk khusus untuk memeriksa pengelolaan dan pertanggungjawaban keuangan negara yang dikenal kenal sebgai Badan Pemeriksa Keuangan (BPK). ${ }^{2}$ Pemeriksaan BPK dilakukan terhadap pemerintah pusat, pemerintah daerah, lembaga negara lainnya, Bank Indonesia, badan usaha milik negara, badan layanan umum, badan usaha milik daerah dan lembaga atau badan lain yang mengelola keuangan negara. Untuk mendukung pelaksanaan tugasnya, BPK juga memiliki kewenangan memberikan pendapat yang diperlukan karena sifat pekerjaannya, menilai dan/ atau menetapkan kerugian negara, memberikan pertimbangan atas penyelesaian kerugian negara/ daerah, dan memberikan keterangan ahli dalam proses peradilan mengenai kerugian negara/ daerah (Badan Pemeriksa Keuangan, 2018: xviii).

Semester I tahun 2018 BPK melakukan pemeriksaan tehadap lembaga atau badan baik pusat maupun daerah yang mengelola keuangan negara yang dengan rincian sebagai berikut: 652 Laporan Hasil Pemeriksaan keuangan (93\%), 12 Laporan Hasil Pemeriksaan kinerja dan 36 Laporan Hasil Pemeriksaan dengan tujuan tertentu dengan 9.808 temuan dan 26.871 rekomendasi. Dari hasil pemeriksaan atas laporan keuangan memuat opini Wajar Tanpa Pengecualian terhadap 512 dari 652 laporan keuangan (Badan Pemeriksa Keuangan, 2018: xxvi). BPK mengungkapkan 9.808 temuan yang memuat 15.773 permasalahan, meliputi 7.539 (48\%) permasalahan kelemahan sistem pengendalian intern (SPI) dan 8.030 (51\%) permasalahan ketidakpatuhan terhadap ketentuan peraturan perundang-undangan senilai Rp10,06 triliun, serta 204 (1\%) permasalahan ketidakhematan, ketidakefisienan, dan ketidakefektifan senilai Rp1,49 triliun (Badan 
Pemeriksa Keuangan, 2018: xvi). Berdasarkan temuan pemeriksaan BPK yang menggunakan standar pemeriksaan keuangan negara yang disampaikan kepada instansi yang berwenang periode 2003 s.d. 30 Juni 2017, terdapat 5 hasil pemeriksaan investigatif dengan nilai indikasi kerugian negara/ daerah sebesar Rp522,97 miliar dan 7 hasil penghitungan kerugian negara/daerah dengan nilai kerugian negara/daerah sebesar Rp7,99 triliun yang laporannya telah disampaikan kepada instansi yang berwenang (Badan Pemeriksa Keuangan, 2018: 236).

Merujuk pada fakta yang dipaparkan diatas, maka manuver agresif harus dilakukan untuk menutup celah korupsi dan meminimalisir kerugian negara dan terwujudnya good and clean governance. Kerjasama pelbagai pihak untuk menutup celah korupsi menjadi sebuah keharusan. Maka dari itu, tulisan ini akan membahas tentang salah satu upaya pemerintah untuk menutup celah korupsi melalui kolaborasi, sinergitas antar aktor baik aktor internal maupun eksternal dalam pengawasan keuangan negara. dengan metode penelitaian kualitatif deskriptif dan menggunakan desk study sebagai teknik pengumpulan data. Sehubungan dengan pembahasan tersebut, maka tulisan ini akan terdiri dalam beberapa bagian. Pertama yaitu pendahuluan yang menjadi triggers bahwa diperlukan sinkronisasi dan kolaborasi antar aktor untuk menutup rapat seslat-seslat korupsi. Bagian kedua merupakan peletakan pemahaman tentang keuangan negara, serta scope dari keuangan negara tersebut. Sementara itu bagian ketiga akan membahas mengenai kolaborasi aktor sebagai upaya penutupan celah korupsi melalui pengawaan keuangan negara. Terakhir adalah penutup.

\section{Lingkup keuangan negara}

Keuangan negara menjadi modal penting untuk menyokong keberlangsungan negara dalam menjalankan tugasnya dan mencapai tujuan bernegara. Sebagai modal primer, keuangan negara perlu dikelola secara efektif, efisien, ekonomis, transparan dan akuntabel, serta tertib dan taat pada ketentuan peraturan perundang-undangan yang berlaku. Dalam pengelolaan keuangan negara inilah banyak upaya dari berbagai oknum yang tidak bertanggungjawab yang mencari celah untuk menikmati uang negara demi kepentingan personal dan kelompoknya, yang pada akhinya mengakibatkan kerugian negara. Sebelum masuk pada upaya yang harus dilakukan untuk menutup rapat sela-sela keuangan negara, maka perlu memahami terlebih dahulu apa itu keuangan negara dan apa saja lingkupnya.

Keuangan negara menurut Van Der Kemp (dalam Tjandra, 2006: 2) adalah semua hak yang dapat dinilai dengan uang, demikian pula segala sesuatu, baik berupa uang atau barang yang dapat dijadikan milik negara berhubungan dengan hak-hak tersebut. Merujuk pada pasal 1 Undangundang Republik Indonesia Nomor 17 Tahun 2003 Tentang Keuangan Negara, yang dimaksud sebagai keuangan negara adalah semua hak dan kewajiban negara yang dapat dinilai dengan uang, serta segala sesuatu baik berupa uang maupun berupa barang yang dapat dijadikan milik negara berhubung dengan pelaksanaan hak dan kewajiban tersebut. Berikut ini konsep keuangan negara yang dilihat dari beberapa pendekatan. 
Tabel 1. Keuangan Negara Dari Pendekatan Objek, Subjek, Proses Dan Tujuan

\begin{tabular}{|c|c|c|c|}
\hline Objek & Subjek & Proses & Tujuan \\
\hline $\begin{array}{l}\text { Hak dan kewajiban } \\
\text { negara yang dapat } \\
\text { dinilai dengan uang, } \\
\text { serta segala sesuatu baik } \\
\text { berupa uang/ barang } \\
\text { yang dapat dijadikan } \\
\text { milik negara termasuk } \\
\text { kebijakan dan kegiatan } \\
\text { dalam bidang fiskal, } \\
\text { moneter dan pengelolaan } \\
\text { kekayaan negara yang } \\
\text { dipisahkan }\end{array}$ & $\begin{array}{l}\text { Seluruh } \\
\text { obyek keuangan } \\
\text { yang dimiliki negara, } \\
\text { dan/ atau dikuasai } \\
\text { oleh Pemerintah } \\
\text { Pusat, Pemerintah } \\
\text { Daerah, Perusahaan } \\
\text { Negara/ Daerah, dan } \\
\text { badan lain yang ada } \\
\text { kaitannya dengan } \\
\text { keuangan negara }\end{array}$ & $\begin{array}{l}\text { Seluruh rangkaian } \\
\text { kegiatan yang } \\
\text { berkaitan dengan } \\
\text { pengelolaan } \\
\text { obyek keuangan } \\
\text { negara mulai dari } \\
\text { perumusan kebijakan } \\
\text { dan pengambilan } \\
\text { keputusan sampai } \\
\text { dengan } \\
\text { pertanggungg- } \\
\text { jawaban. }\end{array}$ & $\begin{array}{l}\text { Seluruh } \\
\text { kebijakan, kegiatan } \\
\text { dan hubungan } \\
\text { hukum yang } \\
\text { berkaitan dengan } \\
\text { pemilikan dan/atau } \\
\text { penguasaan obyek } \\
\text { keuangan negara } \\
\text { dalam rangka } \\
\text { penyelenggaraan } \\
\text { pemerintahan } \\
\text { negara. }\end{array}$ \\
\hline
\end{tabular}

Sumber : UU Nomor 17 Tahun 2003 tentang Keuangan Negara

Dengan demikian keuangan negara adalah semua hak dan kewajiban negara yang dapat dinilai dengan uang dan/atau barang yang dikuasai oleh pemerintah pusat, pemerintah daerah, Perusahaan Negara/Daerah, dan badan lain yang mengelola keuangan negara mulai dari perumusan kebijakan sampai dengan pertanggunggjawaban, dalam rangka penyelanggaraan fungsi pemerintahan.

Sementara itu, dalam penjelasan UU No.17 Tahun 2003 Pasal 2 dijelaskan bahwa lingkup dari keuangan negara adalah sebagai berikut: a) Hak Negara untuk memungut pajak, mengeluarkan dan mengedakan uang serta melakukan pinjaman; b) Kewajiban Negara untuk menjalankan tugas layanan umum pemerintahan Negara dan membayarkan tagihan pihak ketiga; c) Penerimaan negera; d) Pengeluaran Negara; e) Penerimaan daerah. f) Pengeluaran daerah; g) Kekayaan Negara/ daerah yang dikelola sendiri oleh pihak lain, berupa uang, surat berharga, piutang barang, serta hak hak lain yang dapat dinilai dengan uang,termasuk kekayaan yang dipisahkan pada perusahaan negara atau perusahaan daerah; h) Kekayaan pihak lain yang dikuasai oleh pemerintah dalam rangka penyelenggaraan tugas pemerintahan atau kepentingan umum; dan i) Kekayaan pihak lain yang diperoleh dengan menggunakan fasilitas yang diberikan pemerintah.

\section{Pengamanan keuangan negara melaluil pengawasan}

Untuk menjamin akuntabilitas hasil dan kinerja pengelolaan keuangan negara, maka perlu proses pengawasan yang maksimal agar pelaksanaan anggaran berjalan sebagaimana yang direncanakan. Proses pengawasan ini menjamin agar para pengguna keuangan negara mengelola dan menggunakan anggara secara akuntabel, transparan, patuh dan taat serta tertib pada peraturan perundang-undagan serta memberikan kemanfaatan bagi rakyat. Selain itu, adanya pengawasan 
merupakan salah satu bentuk pengamanan keuangan negara dari fraud risk yang dilakukan oleh pihak-pihak yang mencoba mengambil keuntungan dari negara yang pada akhirnya memberikan dampak kerugian negara. berpijak pada argument tersebut maka perlu setidaknya untuk membahas konsep pengawasan.

Pengawasan merupakan kegiatan untuk memeriksa dan menjamin bahwa setiap kegatan yang dilaksanakan sesuai dengan yang direncanakan. Bisa dikata bahwa pengawasan merupakan tindakan pembimbingan, pengaturan, pemeriksaan, pengendalian agar apa yang telah dirncanakan di awal dapat berjalan dengan baik dan mencapai hasil yang diinginkan (Iskandar Dian, 2018: 181). Pada dasarnya pengawasan proses monitoring performance dan mengambil tindakan untuk mendapatkan hasil yang diinginkan berjalan dengan baik.

Fachruddin (2004, dalam Tjandra, 2006: 133) mengidentifikasi beberapa sudut pandang untuk menentukan jenis pengawasan. Pertama, pengawasan dari sudut pandang kelembagaan. Ada dua kategori untuk jenis ini: a) Internal Control yakni pengawasan yang dilakukan oleh suatu badan atau organ yang secara struktural masih termasuk organisasi dalam lingkungan pemerintah. Bentuk kontrol ini dapat digolongkan sebagai jenis kontrol teknis-administrasi atau built-in control; b) Pengawasan dari segi kemanfaatan (opportunitas) pengawasan dilakukan untuk menilai segi kemanfaatannya (doelnatigheid). Control internal secara hirarkis oleh atasan adalah jenis penilaian segi hokum dan sekaligus segi kemanfaatan. Adapun jenis kedua adalah Pegawasan dari cara pengawasan. Untuk jenis ini juga memiliki dua kategori, yakni: a) Pegawasan represif yang dilakukan setelah suatu tindakan dilaksanakan; b) Pengawasan preventif atau positif. Pengawasan yang dilakukan dengan cara badan pemerintah yang lebih tinggi meghalangi terjadinya kelalaian pemerintah yang lebih rendah. Sedangkan menurut Hertogh (dalam Tjandra, 2006: 135), pengawasan dibedakan menjadi dua. Pertama, pengawasan unilateral, yakni pengawasaan yang penyelesaiannya diakukan secara sepihak oleh pengawas. Kedua, pengawasan refleksif, yaitu pengawasan yang penyelesaiannya dilakukan melalui proses timbal balik berupa dialog dan negosiasi antara pengawasan dan yang diawasi.

Sementara itu Soebagio (dalam Tjandra, 2006: 136) memiliki metode pengawasan diklasifikasikan menjadi tiga, yakni dari segi objek, sifat, dan ruang lingkupnya. Dari Segi objek dibedakan atas: a) Pengawasan terhadap penerimaan negara, meliputi: pengawasan terhadap jenis pajak. Dalam hal ini diutamakan kepada pengawasan represif, sedangkan pengawasan terhadap pungunan non tax dilakukan oleh coordinator secara langsung terhadap instansi. b) Pengawasan terhadap pengeluaran negara, yang dilakukan pada waktu, sedang atau sesudah operasional dan pengawasan pada waktu sebelum dilakukan pengeluaran. Kemudian dari segi sifat, dibedakan menjadi: a) Pengawasan preventif adalah pengawasan yang dilakukan sebelum terjadinya pengeluaran dalam rangka menghindarkan kebocoran dan penghamburan. Pengawasan ini dilaksanakan secara ketat berdasarkan proyeksi keuntungan dari rencana pegeluaran dengan mengunakan metode perbandingan antara besarnya biaya yang dikeluarkan dengan hasil manfaat 
yang diperkirakan akan dapat diperoleh (cost benefit analysis/ volume profit analysis) dengan menggunakan standarisasi biaya. b) Pengawasan represif merupakan kelanjutan dari mata rantai pengasan preventif sehingga dengan dilakukan pengawasan represif ini lengkaplah pengawsan keuangan negara. Terakhir, dari segi ruang lingkup dapat diartikan dalam arti luas dan sempit. Pengawasan yang dilakukan alam tubuh suatu organisasi dimana terdapat hubungan antara pengawas dan pejabat dri suatu departemen terhadap pejabat yang berada di unit organisasiorganiasasi di daerah. Dalam arti luas artinya antara pengawas dan pejabat yang diawasi tidak mempunyai korelasi langsung.

Selain sifat pengawasan yang disampaikan Soebagio, terdapat juga sifat pemeriksaan yang investigative, dimana pemeriksaan investigatif merupakan lanjutan dari pengawasan represi jika ditemukan adanya indikasi kerugian negara. Pengawasan ini menjadi sangat penting demi mastikan apa yang telah direncanakan berjalan sesuai yang diharapkan, dan menekan adanya fraud yang berakibat pada kerugian negara. untuk melakukan pencegahan dan penekanan penyelewengan dalam pengelolaan negara sangat dibutuhkan adanya lembaga-lembaga yang secara khusus melakukan tindakan pengawasan. Dengan demikian, selanjutnya tulisan ini akan mengelaborasi kolaborasi aktor internal maupun eksternal dalam pengawasan keuangan negara.

\section{Kolaborasi aktor internal-eksternal pengawasan keuangan negara}

Sebelum masuk pada tahap dimana aktor internal dan eksternal melakukan pengawasan, maka perlu terlebih dahulu mengidentifikasi satu per satu siapa saja yang menjadi aktor internal maupun eksternal yang memiliki fungsi khusus controlling financial management di Indonesia. Khusus di Indonesia, secara kelembagaan kita dapat membagi pengawasan melalui aktor internal yang bertugas melakukan internal control dan aktor eksternal yang merupakan lembaga yang khusus dibentuk untuk melakukan fungsi pengawasan.

Inspektorat dan BPKP adalah aktor internal pengawasan keuangan negara. Sebagaimana yang disampaikan Fachruddin (2004, dalam Tjandra, 2006: 133) bahwa pengawasan yang dilakukan oleh suatu badan atau organ yang secara struktural masih termasuk organisasi dalam lingkungan pemerintah, disebut dengan internal control. Dalam lingkup pemerintahan Indonesia terdapat dua institusi atau lembaga yang memiliki kewenangan untuk melakukan pengawasan atas penyelenggaraan pemerintahan termasuk dalam pengelolaan keuangan negara. adapun lembaganya yaitu Inspektorat Jenderal atau nama lain yang secara fungsional melakukan pengawasan internal dan Badan Pengawasan Keuangan dan Pembangunan dengan tujuan untuk menciptakan pengelolan keuangan yang akuntable dan transparent serta bebas dari penyalahgunaan anggaran.

Inspektorat Jenderal/ Inspektorat Provinsi/ Inspektorat Kota dan/ atau Kabupaten mempunyai tugas menyelenggarakan pengawasan internal atas pelaksanaan tugas di lingkungan pemerintah pusat baik kementerian atau lembaga dan badan, serta di lingkup pemerintah daerah. Inspektorat dalam menyelenggarakan pengawasan internal melalui kegiatan audit, revieu, evaluasi dan 
pemantauan, serta kegiatan pengawasan lainnya terhadap penyelenggaraan tugas dan fungsi dari masing-masing instansi pemerintahan termasuk dalam pengelolaan keuangan oleh semua entitas yang memanfaatkan keuangan negara. agar terciptanya pengelolaan keuangan negara yang efektif dan efisien, transparan, akuntabel, serta tertib dan patuh pada peraturan perundang-undangan. Dalam melaksanakan tugasnya Inspektorat mempunyai fungsi untuk menyusun kebijakan teknis pengawasan internal dalam lingkungan masing-masing unitnya, melakukan pengawasan dengan tujuan tertentu sesuai dengan penugasan yang diberikan oleh pimpinan, seperti menteri, gubernur, bupati dan walikota, seain itu juga membuat laporan hasil pengawasan atas pelaksanaan tugas sebagai bentuk pertanggung-jawaban.

Aktor selanjutnya yaitu Badan Pengawasan Keuangan dan Pembangunan. Berdasarkan Peraturan Presiden Nomor 192 Tahun 2014 tentang Badan Pengawasan Keuangan dan Pembangunan, menyatakan bahwa badan ini mempunyai tugas untuk melakukan pengawasan keuangan negera/daerah dan pembangunan nasional. Dengan menjalankan beberapa fungsi sebagaimana yang dituangkan dalam pasal 3 peraturan tersebut, antara lain: merumuskan kebijakan nasional pengawasan internal terhadap akuntabilatas keuangan nasional/daerah dan pembangunan nasional. Pelaksanaan pengawasan internal terhadap perencanaan, pelaksanaan dan pertanggungjawaban akuntabilitas keuangan negara dan daerah serta perencanaan dan pelaksanaan pemanfaatan asset negara dan daerah. Melakukan pengendalian internal, memberikan konsultasi terhadap manajemen resiko. Melakukan upaya pencegahan korupsi. Koordinasi dan sinegi dalam melakukan pengawasan intern terhadap akuntabilitas keuanngan negara/daerah. Melakukan review atas laporan keuangan dan laporan kinerja pemerintah pusat, melakukan sosialisasi, pembimbingan dan konsultasi penyelenggaraan sistem pengendalian internal, dan lain-lain. Dalam pelaksanaan tugasnnya BPKP bertanggungjawab pada presiden.

Kedua lembaga ini, baik Inspektorat maupun BPKP merupakan entitas yang menjadi unsur dalam penyelenggara dalam sistem pengendalian internal pemerintahan secara menyeluruh baik pemerintahan pusat maupun pemerintahan daerah. Kedua lembaga pengawasan internal ini dikenal sebagai aparat pengawas internal pemerintahan yang melakukan pengendalian internal ini untuk memberikan keyakinan yang memadai atas tercapainya tujuan organisasi pemerintahan secara efektif dan efisien, tak terkecuali dalam pengelolaan keuangan negara demi meningkatkan akuntabilitas dan pemenuhan prinsip-prinsip pengelolaan keuangan negara, serta kehandalan laporan keuangannya. Selain itu juga taat pada peraturan yang berlaku.

Adapun aktor eksternal pengawasan keuangan negara adalah badan pemeriksa keuangan dan lembaga legislatif.Kontrol eksternal dalam pengelolaan keuangan negara dilakukan oleh BPK dan DPR, DPD dan DPRD Dimana hasil pemeriksaan dan pengawasan yang dilakukan berdampak pada penyusunan anggaran negara ditahun berikutnya. Badan Pemeriksa Keuangan secara konstitusional dalam undang-undang dasar republik Indonesia tahun 19940 pasal 23E merupakan lembaga yang bebas dan mandiri dan objektif yang berwenang untuk memeriksa pegelolaan keuangan 
negara dan pertanggungjawabannya karena terkait dengan akuntabilitas pemerintah. Pemeriksaan yang dilakukan oleh BPK bertujuan untuk menjaga agar anggaran yang disusun dapat dijalankan, kegiatan pengumpulan penerimaan dan pembelanjaan negara sesuai dengan yang telah ditentukan serta agar pelaksanaan APBN/APBD dapat dipertanggungjawabkan. Pemeriksaan yang dilakukan sesuai dengan standar akuntansi pemerintahan sesuai degan peraturan pemerintah nomor 24 tahun 2005 tentang standar akuntansi pemerintahan. Selain itu untuk menyokong tata kelola keuangan negara yang baik melalui perolehan keyakinan sesuai dengan prinsip pengelolaan yang baik dan peraturan perundang-undangan yang berlaku.

Pemeriksaan yang dilakukan oleh BPK adalah proses identifikasi masalah, analisis, dan evaluasi yang dilakukan secara independen, objektif, dan profesional berdasarkan standar pemeriksaan, untuk menilai kebenaran, kecermatan, kredibilitas, dan keandalan informasi mengenai pengelolaan dan tanggung jawab keuangan negara. ${ }^{3}$ Hasil pemeriksaan yang dilakukan BPK kemudian disampaikan kepada lembaga legislatif yang sesuai dengan wewenangnya. Hasil dari pemeriksaan itu digunakan dan ditindaklanjuti oleh badan legislatif dan badan lainnya sesuai dengan undangundang.

Dalam pelaksanaan tugasnya BPK memiliki wewenang untuk menentukan objek pemeriksaan, merencanakan dan melaksanakan pemeriksaan, menentukan waktu dan metode pemeriksaan serta menyusun dan menyajikan laporan pemeriksaan. meminta keterangan dan/atau dokumen yang wajib diberikan oleh setiap orang, unit organisasi Pemerintah Pusat, Pemerintah Daerah, Lembaga Negara lainnya, Bank Indonesia (BI), Badan Usaha Milik Negara (BUMN), Badan Layanan Umum (BLU), Badan Usaha Milik Daerah (BUMD), dan lembaga atau badan lain yang mengelola keuangan negara. melakukan pemeriksaan di tempat penyimpanan uang dan barang milik negara, di tempat pelaksanaan kegiatan, pembukuan dan tata usaha keuangan negara, serta pemeriksaan terhadap perhitungan-perhitungan, surat-surat, bukti-bukti, rekening koran, pertanggungjawaban, dan daftar lainnya yang berkaitan dengan pengelolaan keuangan negara menetapkan jenis dokumen, data, serta informasi mengenai pengelolaan dan tanggung jawab keuangan negara yang wajib disampaikan kepada BPK. Menetapkan standar pemeriksaan keuangan negara setelah konsultasi dengan Pemerintah Pusat/Pemerintah Daerah yang wajib digunakan dalam pemeriksaan pengelolaan dan tanggung jawab keuangan negara. ${ }^{4}$

Selanjutnya adalah lembaga legislatif baik itu DPR maupun DPRD dan DPD. Dalam melaksanakan tugasnya lembaga legislatif memiliki 3 fungsi yang salah satunya adalah fungsi pengawasan. Dalam hal ini, fungsi pengawasan dilakukan melalui pengawasan atas pelaksanaan undang undang dan APBN/ APBD, ${ }^{5}$ serta kebijakan pemerintah. Sebagai lembaga legislatif yang dalam pelaksanaan tugas, terdapat beberapa komisi, salah satunya adalah komisi yang bertugas di bidang pengawasan. Dalam undang-undang nomor 17 tahun 2014 tentang Majelis Permusyawaratah Rakyat, Dewan Perwailan Rakyat, Dewan Perwakkilan Daerah dan Dewan Perwakilan Rakyat Daerah menyatakan tugas komisi dibidang pengawasan tersebut berkaitan dengan pengawasan 
terhadap pelaksanaan undang-undang termasuk APBN/APBD, serta peraturan pelaksanaanya yang termasuk dalam ruang lingkup tugasnya. Tugas berikutnya yaitu membahas dan menindaklanjuti hasil pemeriksaan BPK atas pertanggungjawaban keuangan negara serta memberikan masukan kepada BPK yang berkaitan degan rencana kerja pemeriksaan tahunan, kemudian yang terkait dengan hambatan pemeriksaan serta penyajian dan kualitas laporan. Kegiatan pengawasan yang dilakukan oleh lembaga legislatif tidak lepas dari dukungan fungsi BPK yang merupakan badan kusus yang berwewenang memeriksa pertanggung jawaban negara.

Kedua aktor eksternal dalam pengawasan keuangan negara ini saling berkaitan, karena Badan Pemeriksa Keuangan akan menyampaikan hasil laporan pemeriksaan kepada lembaga legislatif. Laporan hasil pemeriksaan yang diserahkan oleh BPK menjadi dasar pengambilan keputusan bagi legislatif untuk menentukan penyetujan APBN/APBD tahun berikutnya yang diusulkan oleh eksekutif. Di sisi lain legislatif menjadi penentu atas kebermanfaatan laporan hasil pemeriksaan yang dilakukan oleh BPK sebagai auditor government board dalam mencegah dan meminimalisir terjadinya penyimpangan dan pelanggaraan dalam pengelolaan keuangan negara.

\section{Kolaborasi aktor internal eksternal pengawasan keuangan negara}

Berlandaskan paparan diatas yang telah mengidentifikasi satu persatu pemain dalam pengawasan keuangan negara, maka pada bagian ini akan membahas betapa pentingnya dan urgennya koordinasi, kolaborasi, sinergisitas dan keharmonian lembaga lembaga atau aktor tersebut dalam menutup rapat celah korupsi di negara ini. Ada beberapa benang merah yang menghubungkan antar aktor internal dan eksternal dalam mengamankan keuangan negara dari ancaman atau potensi kerugian negara.

Pertama dilihat melalui standar pemeriksaan yang digunakan untuk menjalankan tugas pemeriksaan. Dalam hal ini BPK membuat standar pemeriksaan keuangan negara (SPKN) yang dapat digunakan oleh BPK, akuntan publik atau pihak lainnya yang melakukan pemeriksaan atas pengelolaan dan tanggung jawab keuangan negara untuk dan atas nama BPK, akuntan publik yang melakukan periksaan keuangan negara berdasarkan ketentuan undang-undang serta Aparat Pengawas Intern Pemerintah dalam hal ini adalah inspektorat dan BPKP yang melakukan audit kinerja dan audit dengan tujuan tertentu. ${ }^{6} \mathrm{Hal}$ ini juga berlaku untuk seluruh entitas, program dan berkaitan engan pengeloaan dan tanggung jawab negara demi menciptakan pegelolaan yang lebih baik, akuntabel, transparan, efisien dan efektif yang pada akhirnya berimbas pada peningkatan kesejahteraan rakyat, karena pengelolaan negara dimanfaatkan untuk kepentingan negara dalam menjalankan tugas dan fungsinya yang berhilir pada cita-cita ketika negara ini dibentuk.

Dalam penerapan SPKN ini, BPK membentuk komite yang bertugas untuk mengevaluasi penerapan standar pemeriksaan keuangan negara. Ini semua dilakukan untuk mewujudkan pemerintahan yang good and clean governance yang bebas dari korupsi. Adanya standar pemeriksaan yang berbasis prinsip ini menujukan bahwa masing masing lembaga fungsional 
pengawasan memiliki pedoman atau tolak ukur yang sama dalam memaksakan akuntabilitas pengelolaan keuangan negara.

Kedua yaitu adanya system pengendalian internal yang dilakukan oleh masing masing lembaga yang menjadi bermanfaat dan pengguna dari keuangan negara. pengendalian internal dilakukan oleh pimpinan masing-masing intansi dan aparat pengawas internal pemerintahan dalam hal ini adalah Inspektorat dan BPKP. Hal ini dilakukan demi menjaga kehandalan dan kewajaran dari penggunaan keuangan negara. komitmen pimpinan menjadi hal penting dalam kegiatan pengawasan ini terutama melakukan pre audit. Pengawasan melekat yang dilakukan pimpinan yang sifat dari pengawasan ini adalah preventif untuk mencegah terjadi penyimpangan pelaksanaan keuangan dari rencana yang telah ditetapkan diawal tahun anggaran, kelebihan pengendalian internal yang dilakukan pimpinan instansi yaitu dapat melakukan pengawasan di setiap waktu, yang kita kenal sebagai feedforward control, concurrent control dan feedback control, atau juga Apriori dan Apostpriori control, sebelum kegiatan atau anggaran dilaksanakan, saat dilaksanakan serta setelah dilaksanakan. Untuk menjaga dari kecurangan dalam penggunaan anggaran maka komitmen dan konsistenitas pimpinan dalam melakukan pengawasan melekat menjadi hal yang sangat fundamental dalam mengamankan keuangan negara dan mengindarkan dari kebocoran dan penyimpangan. Selain komitmen dan konsistensi pimpinan instansi, aparat pengawasan internal baik inspektorat maupun BPKB melakukan post audit. Demi mencegah dan menemukan kerugian negara. Dengan demikian kolaborasi antar aktor internal maupun eksternal merupakan bentuk dari penguatan upaya pemberantasan korupsi dan kerugian dalam pengelolaan keuangan negara.

\section{Penutup}

Berdasarkan paparan yang telah disampaikan di atas, terdapat beberapa poin penting dalam menutup celah korupsi dan pengamanan pengelolaan dan pertanggungjawaban keuangan negara. Pertama, perlunya melakukan pengawasan keuangan negara dalam semua waktu, baik sebelum, sedang dan setelah (feedforward, concurrent dan feedback control) dilaksanakannya penggunaan anggaran atau keuangan negara. Kedua, komitmen, kolaborasi, koordinasi dan sinergitas antar aktor menjadi landasan dasar untuk memperpendek ruang gerak untuk mencari celah penyalahgunaan pemanafaatan keuangan negara oleh pihak yang tidak bertanggungjawab.

Peran aktor baik itu pimpinan instansi sebagai pengguna keuangan negara, maupun aktor pengawasan fungsional baik internal maupun eksternal sangat besar dalam menjaga pengelolaan dan tanggungjawab pengelolaan negara agar akuntabel. Selain itu, gerak cepat, tepat, cermat dan tangkas dari aktor pengawasan keuangan negara menjadi bagian penting dalam mencapai cita-cita negara yang bersih dan baik. Beberapa hal itulah yang menjadi kunci dalam menekan dan memblokade praktik korupsi dan menghindarkan negara dari kerugian. 


\section{Ucapan Terima Kasih}

Terima kasih pada rekan-rekan penulis di Sekolah Vokasi Keuangan Publik atas diskusidiskusinya.

\section{Pendanaan}

Penulis tidak menerima bantuan pembiayaan untuk penelitian, kepenulisan (authorship), dan publikasi dari pihak manapun.

\section{Catatan}

1 Dijelaskan lebih lanjut dalam Tempo.co (2018) bahwa hasil penelitian Indonesia Corruption Watch menyatakan Tahun 2016 terdapat 482 kasus korupsi, dan terdapat 576 kasus korupsi sepanjang 2017 yang menyebabkan kerugian negara sebesar 6,5 triliun rupiah dan nilai suap 211 miliar rupiah.

2 Lihat Pasal 23E pada Undang-Undang Dasar Negara Republik Indonesia 1945.

3 Lihat Peraturan BPK Nomor 1 Tahun 2017 Tentang Standar Pemeriksaan Keuangan Negara.

4 Dalam kewenangan BPK juga terdapat kewenangan yang berkaitan dengan masalah teknis, kode etik danbahkan dalam hal pengembangan SDM, serta pemantauan pelaksanaan ganti rugi keuangan negara. Kerangka konseptual pemeriksaan yang dikeluarkan oleh BPK sesuai dengan Peraturan BPK Nomor 1 Tahun 2017 Tentang Standar Pemeriksaan Keuangan Negara (h. 6-7).

5 Lihat Pasal 70 pada Undang-undang RepubliK Indonesia nomor 17 tahun 2014 tentang Majelis Permusyawaratan Rakyat, Dewan Perwakilan Rakyat, Dewan Perwakilan Daerah, Dewan Perwakilan Rakyat Daerah.

6 Lihat Pasal 5 pada Peraturan BPK Nomor 1 Tahun 2017 Tentang Standar Pemeriksaan Keuangan Negara.

\section{Dartar pustaka}

Alamsyah, W., Abid, L., \& Sunaryanto, A. (2018). Laporan Tren Penindakan Kasus Korupsi Tahun 2018. Jakarta. Diakses dari https://antikorupsi.org/sites/default/files/laporan_tren_ penindakan_kasus_korupsi_2018.pdf

Badan Pemeriksa Keuangan. (2018). Ikhtisar Hasil Pemeriksaan Semester 1 tahun 2018. Jakarta. BBC Indonesia. (2019). KPK sebut potensi kerugian Rp200 triliun pada 2019, apakah OTT akan lebih sering? Diakses pada 21 April 2019, dari https://www.bbc.com/indonesia/ indonesia-46728691

Iskandar Dian. (2018). Pengawasan keuangan daerah : Salah satu upaya preventif korupsi di Tingkat Lokal. Jurnal Ekomadania, 1(2). Diakses dari http://ejournal.kopertais4.or.id/madura/ index.php/ekomadania/article/view/3180 
Dian Iskandar $\mid$ Menutup celah korupsi melalui kolaborasi antar aktor dalam pengawasan...

Tempo.co. (2018). Kasus Korupsi Tahun 2017, ICW: Kerugian Negara Rp 6,5 Triliun. Diakses pada 21 April 2019, dari https://nasional.tempo.co/read/1062534/kasus-korupsi-tahun-2017-icwkerugian-negara-rp-65-triliun

Tjandra, W. R. (2006). Hukum Keuangan Negara. Jakarta: Grasindo.

Transparency International. (2018). Corruption Perceptions Index 2018. Diakses pada 21 April 2019, dari https://www.transparency.org/cpi2018

\section{Tentang Penulis}

Dian Iskandar adalah Dosen Sekolah Vokasi, Prodi Keuangan Publik, Universitas Diponegoro. 